\section{RISET STRATEGI IMPLEMENTASI C-RAN DI TELKOMSEL MELALUI KOLABORASI JARINGAN NG-PON2 DI TELKOM AKSES MENGGUNAKAN PENDEKATAN METODE STRATEGIC SITUATION ANALYSIS}

\section{RESEARCH STRATEGY OF C-RAN IMPLEMENTATION IN TELKOMSEL THROUGH COLLABORATION OF NG-PON2 NETWORK IN TELKOM ACCESS USING STRATEGIC SITUATION ANALYSIS METHOD APPROACH}

\author{
Tri Susanto ${ }^{1}$, K.J. Hartono ${ }^{2}$ dan Bilpen Nainggolan ${ }^{3}$
}

Divisi Digital Service, PT. Telekomunikasi Indonesia, Tbk. 1trissto@,telkom.co.id 2ijhartono@telkom.co.id s bil@telkom.co.id

\section{JURNAL \\ MANAJEMEN \\ INDONESIA}

Vol. 17 - No. 1

April 2017

\title{
Abstrak
}

Cloud Radio Access Network (C-RAN) adalah teknologi akses radio yang diyakini mampu menekan biaya CAPEX dan OPEX dari mobile operator dan memberikan performansi yang lebih baik dibandingkan Radio Access Network (RAN) tradisional. Salah satu faktor kunci sukses implementasi C-RAN adalah penyediaan jaringan fonthaul yang efektif. Tujuan penelitian ini adalah membuat strategi implementasi C-RAN di Telkomsel melalui kolaborasi jaringan NG-PON2 di Telkom Akses. Pada tulisan ini menggunakan metode analisis kualitatif dengan melakukan strategy situation analysis (SSA) yaitu melakukan analisa data eksternal maupun internal dan selanjutnya diformulasikan sebagai dasar pembuatan strategi implementasi. Dari penelitian ini dihasilkan usulan strategi implementasi C-RAN di Telkomsel melalui kolaborasi jaringan NG-PON2 di Telkom Akses.

Kata kunci: Kolaborasi, migrasi, FTTx, C-RAN, NG-PON2.

\section{Abstract}

Cloud Radio Access Network (C-RAN) is a radio access technology which is believed to reduce the cost of CAPEX and OPEX of mobile operators and provides better performance than traditional Radio Access Network (RAN). One key factor in the successful implementation of C-RAN is the provision of effective front haul network. The purpose of this research is to make C-RAN implementation strategy in Telkomsel through NG-PON2 network collaboration in Telkom Access. In this paper using qualitative analysis method by conducting a strategy situation analysis (SSA) that is to analyze the external and internal data and then formulated as the basis for making implementation strategy. From this research, the proposed C-RAN implementation strategy in Telkomsel through the collaboration of NGPON2 network in Telkom Access.

Keywords: Kolaborasi, migrasi, FTTx, C-RAN, NG-PON2.

\section{Pendahuluan}

Jumlah pelanggan seluler (mobile) dan trafik data mobile secara global maupun nasional diperkirakan semakin tumbuh sangat signifikan. Pertumbuhan ini sangat dipengaruhi oleh perubahan life style dari pelanggan. Namun demikian besarnya pertumbuhan trafik data mobile tidak serta merta diiringi dengan pertumbuhan revenue yang didapat oleh mobile operator sehingga muncullah gap. Gap muncul disebabkan oleh besarnya biaya CAPEX dan OPEX yang harus dikeluarkan perusahaan tidak sebanding dengan revenue yang didapatkan (Zaid, 2015; Aleksandra dkk., 2015). Dengan dilatarbelakangi adanya permasalahan tersebut maka muncullah konsep arsitektur Cloud Radio Access Network (C-RAN) yang mampu menekan biaya CAPEX dan OPEX (C-RAN, 2013). Namun demikian implementasi arsitektur C-RAN bukan tidak ada tantangan. Tantangan yang paling besar akan dihadapi oleh operator adalah penyediaan jaringan fronthaul menggunakan kabel serat optik (Dimitris, 2015). Jaringan 


\section{JURNAL \\ MANAJEMEN \\ INDONESIA}

Vol. 17 - No. 1

April 2017

Gambar 1.

Aristektur C-RAN

(Sumber: Checko dkk., 2014)

Gambar 2.

Penghematan CAPEX/ OPEX Melalui Konsep BBU Centrailzed (Sumber: C-RAN, 2013) fronthaul adalah jaringan yang menghubungkan perangkat radio di site ke perangkat base band unit (BBU) di sentral. Mengapa penyediaan jaringan fronthaul menjadi tantangan yaitu disebabkan karena dalam melakukan penggelaran jaringan kabel serat optik membutuhkan investasi yang besar sehingga dapat menghilangkan konsep lahirnya arsitektur C-RAN yaitu menekan biaya CAPEX dan OPEX. Oleh karena itu salah satu kunci sukses implementasi C-RAN adalah pemilihan jaringan fronthaul yang tepat (Dimitris, 2015). Salah satu solusi penyediaan jaringan fronthaul adalah melalui penggunaan jaringan serat optik pada NG-PON2 yang dapat diimplementasikan di Telkom Akses.

Kolaborasi jaringan C-RAN Telkomsel dengan FTTx Telkom Akses akan menjadi solusi untuk penyediaan layanan broadband yang efektif untuk masa yang akan datang sehingga perlu dibuat strategi implementasinya.

\section{Landasan Teori}

\subsection{Teknologi C-RAN}

Konsep arsitektur C-RAN lahir dalam rangka untuk menekan biaya CAPEX (Capital Expenditure) dan OPEX (Operational Expenditure) di cell site dimana merupakan komponen biaya terbesar dibandingkan komponen biaya lain (C-RAN, 2013) yaitu dengan cara memindahkan setiap perangkat baseband unit (BBU) pada cell site ke dalam satu tempat (centralized) (Aleksandra dkk., 2014) dan selanjutnya dilakukan proses virtualisasi pada fungsi-fungsi BBU tersebut. Perangkat BBU sendiri adalah sebuah perangkat Digital Signal Processor (DSP) yang memiliki beberapa fungsi diantaranya memproses signal baseband, menyediakan inteface radio.Contoh arsitektur C-RAN dapat dilihat pada gambar 1.

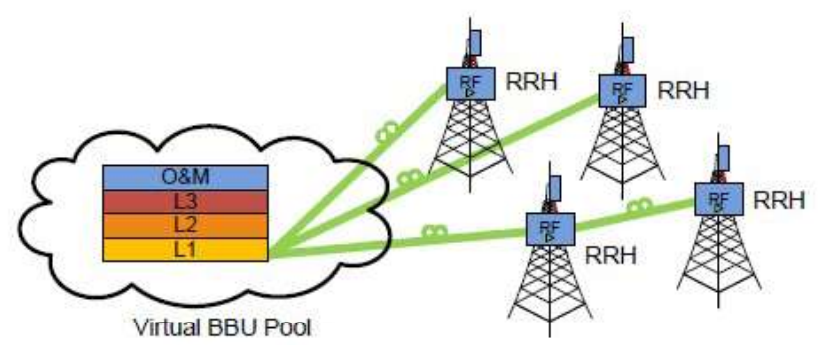

Penghematan biaya yang didapat melalui arsitektur C-RAN berasal dari penghematan biaya meliputi pengadaan perangkat AC (Air Conditioning), perangkat transmisi, pekerjaan sipil, perangkat shelter, perangkat catu daya. Sedangkan penghematan yang berasal dari biaya operasional meliputi biaya konsumsi listrik, operasi dan pemeliharaan dan sewa site. Jadi pada arsitektur C-RAN, hanya perangkat Remote Radio Head (RRH) atau Remote Radio Unit (RRU) yang terdapat pada cell site dimana selanjutnya dihubungkan ke BBU dengan menggunakan jaringan fronthaul.

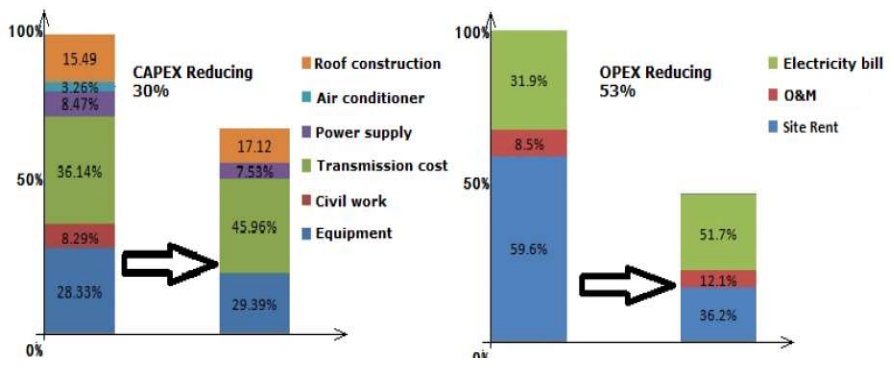

Selain dapat menghemat biaya OPEX dan CAPEX ada beberapa keunggulan lain yang diperoleh menggunakan arsitektur C-RAN dibandingkan dengan RAN tradisional yaitu (C-RAN, 2013) : dapat meningkatkan kapasitas jaringan, mengurangi latency, mengurangi kompleksitas jaringan, mengurangi beban trafik di backhaul maupun di jaringan core, memberikan kualitas layanan yang bagus ke user dengan berbagai macam aplikasi, kemudahan dalam penambahan dan upgrading perangkat BBU, kemudahan 
dalam me-manage dan memonitor BTS serta C-RAN mampu mengakomodasi dan memfasilitasi beberapa teknologi yang digunakan pada teknologi $5 \mathrm{G}$.

\subsection{Teknologi PON pada FTTx}

FTTx adalah kepanjangan dari Fiber to The $x$ yaitu jaringan akses serat optik berbasis teknologi Passive Optical Network (PON) yang menghubungkan perangkat OLT (Optical Line Teriminal) di sentral ke perangkat ONU (Optical Network Unit) atau ONT (Optical Network Terminal) yang berada di rumah (Fiber To The Home), atau di gedung (Fiber To The Building) atau di pinggir jalan (Fiber To The Curb) atau yang berada di tower (Fiber To The Tower). Arsitektur FTTx secara umum dapat dilihat pada gambar 3. PON adalah teknologi jaringan akses serat optik yang dikembangkan oleh ITU-T pada standar G.983 yang menawarkan layanan suara dan data dengan bandwidth 622 Mbps. Teknologi PON berkembang dan berevolusi menjadi GPON. GPON kemudian berkembang menjadi XGPON. Teknologi PON yang terbaru adalah NG-PON2. GPON (Gigabit Capable Passive Optical Network) adalah teknologi jaringan akses serat optik yang distandarkan pada ITU-T G.984 yang menawarkan bit rate sampai dengan 2,4 Gbps sehingga dapat digunakan untuk layanan suara, data dan video. Sedangkan XGPON (10 Gigabit Capable Passive Optical Network) adalah teknologi jaringan akses serat optik yang distandarkan pada ITU-T G.987 yang menawarkan bit rate lebih tinggi dibandingkan dengan GPON yaitu sampai dengan $10 \mathrm{Gbps}$. Teknologi XGPON sendiri dapat dibilang teknologi antara menuju teknologi NG-PON2. Teknologi NG-PON2 akan dijelaskan pada bab selanjutnya.

Jaringan FTTx Telkom saat ini menggunakan jaringan GPON maupun XGPON untuk menyediakan layanan triple play yaitu teleponi, data/internet dan IPTV di perumahan (Fiber to The Home) atau di gedung (Fiber to The Building).

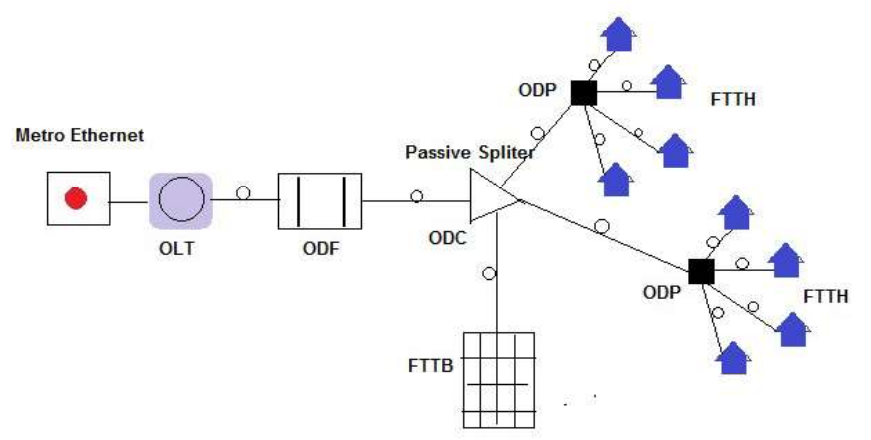

Komponen utama dari jaringan FTTx antara lain meliputi perangkat OLT (Optical Line Terminal) yang terletak di sentral telepon, ODF (Optical Distribution Frame), Optical Distribution (ODC) yang menyediakan fungsi splitter untuk memecah kabel feeder optik ke beberapa kabel distribusi, Optical Distribution Point (ODP) sebagai titik distribusi kabel distribusi beberapa saluran kabel drop di rumah pelanggan. Titik ujung dari jaringan FTTx adalah perangkat ONU/ONT yang terletak di rumah pelanggan atau gedung yang meyediakan interface ke terminal pelanggan. Tipe serat optik yang digunakan antara OLT sampai dengan ODP adalah jenis G.652 sedangkan tipe serat optik yang digunakan antara ODP sampai ke rumah pelanggan menggunakan jenis G.657. Passive splitter yang digunakan pada jaringan Telkom memiliki tipe maksimum sampai dengan 1:4 di sisi ODC dan 1:8 di sisi ODP.

2.3

\section{Teknologi NG-PON2}

NG-PON2 adalah teknologi jaringan serat optik berbasis teknologi PON yang distandarkan ITU-T G.989 yang menawarkan beberapa keunggulan dibandingkan GPON maupun XGPON. Konsep dari arsitektur NG-PON2 lahir dengan tujuan mengintegerasikan semua jenis layanan (multi service) ke dalam satu jaringan baik layanan radio maupun layanan fixed broadband seperti yang diilustrasikan pada gambar 4. Sedangkan arsitektur NG-PON2 berdasarkan ITU-T G.989 dapat dilihat pada gambar 5 .
JURNAL

MANAJEMEN

INDONESIA

Vol. 17 - No. 1

April 2017

Gambar 3 .

Konfigurasi

Jaringan FTTx (TCU,

2017) 


\section{JURNAL}

MANAJEMEN

INDONESIA

Vol. 17 - No. 1

April 2017

\section{Gambar 4.}

Integerasi Multi Service Dalam Satu Jaringan OAN (Optical Access Network)

\section{Gambar 5.}

Arsitektur logik NGPON2 (ITU-T G.989, 2015)

\section{Tabel 1.}

Perbandingan GPON, XGPON dan NGPON2 (Sumber: ITU-T G.989.2, 2015; ITU-T G.984.1, 2008; ITU-T G.989.1, 2008; Mrtin dkk., 2015; ITU-T G.984.3, 2014; ITU-T G.987.1, 2016)
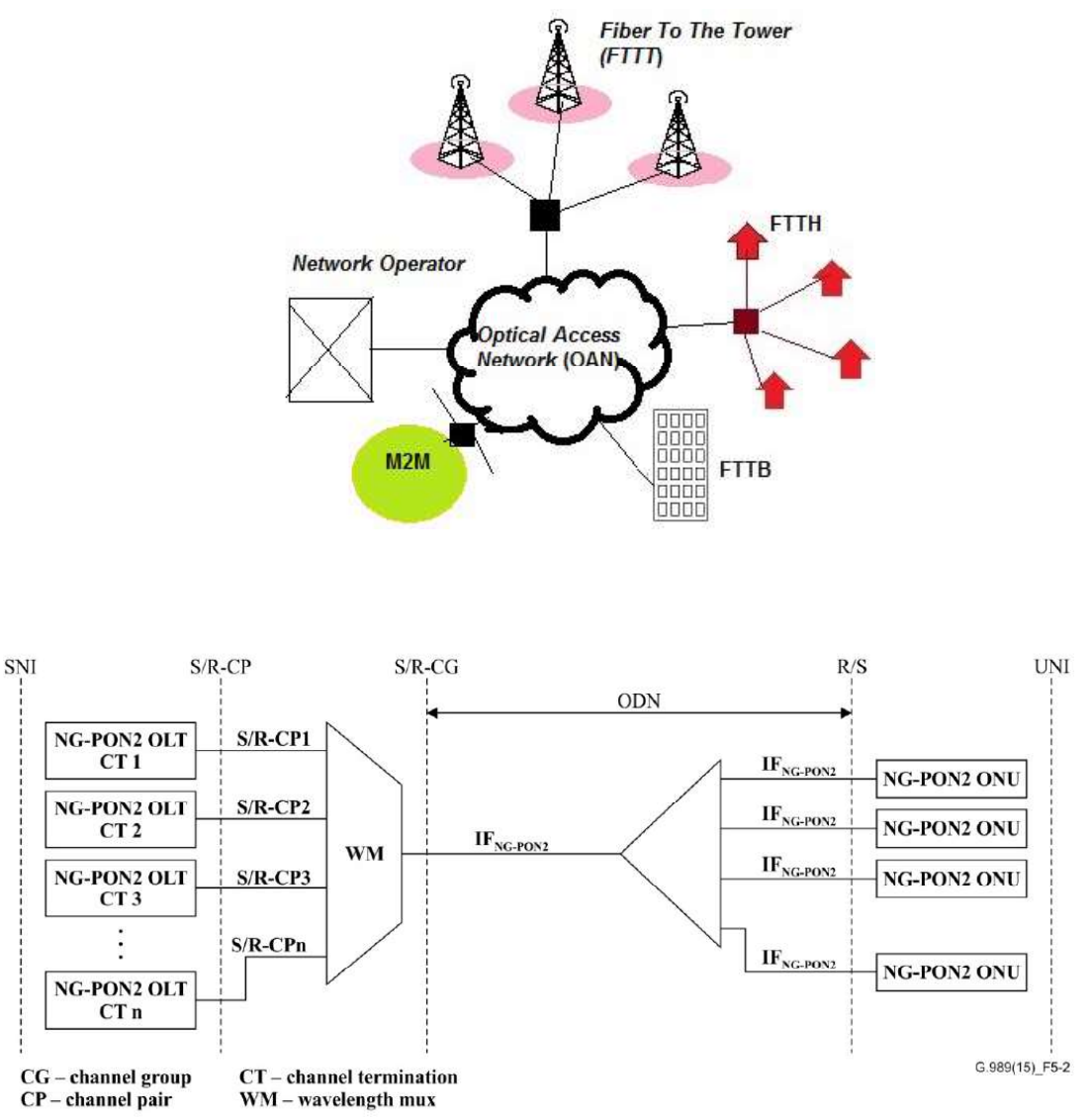

Adapun perbandingan karakteristik dari GPON, XGPON dengan NG-PON2 dapat dilihat pada tabel 1 berikut, dimana teknologi NG-PON2 terbagi atas 2 yaitu TWDM PON dan PtP WDM PON (ITU-T G.989.2, 2015). TWDM PON (Time Wavelength Division Multiplexing PON) adalah gabungan dari teknologi Tme Division Multiplexing (TDM) PON dan Wavelength Division Multiplexing (WDM) PON sehingga memperoleh banyak keuntungan dengan memanfaatkan keunggulan kedua teknologi tersebut. Dengan menggunakan teknologi TDM PON dapat mengakomodasi banyak pelanggan secara efisien sementara dengan menggunakan WDM PON dapat meningkatkan kapasitas bandwidth serta meningkatkan jarak jangkauan layanan. PtP WDM (Point to Point WDM) adalah sistem jaringan NG-PON2 yang digunakan untuk layanan mobile dengan latensi rendah. Jadi C-RAN sangat sesuai dengan menggunakan teknologi ini.

\begin{tabular}{|c|c|c|c|c|}
\hline \multirow[b]{2}{*}{ Parameter } & \multirow[b]{2}{*}{ GPON[10][13] } & \multirow[b]{2}{*}{ XGPON[14] } & \multicolumn{2}{|c|}{ NG-PON2 } \\
\hline & & & $\begin{array}{c}\text { TWDM PON[11] } \\
{[8]}\end{array}$ & $\begin{array}{l}\text { PtP WDM } \\
\text { PON[12][8] }\end{array}$ \\
\hline Bit Rate & $\begin{array}{l}\text { 1,2 Gbps (Up) } \\
\text { 2,4 Gbps (Down) } \\
\text { atau pilihan lain: } \\
\text { 2,4 Gbps (Up) } \\
\text { 2,4 Gbps (Down) }\end{array}$ & $\begin{array}{l}2,5 \text { Gbps }(U p) \\
10 \text { Gbps (Down) }\end{array}$ & $\begin{array}{l}10 \mathrm{Gbit} / \mathrm{s} / \mathrm{ch} \\
(\text { downstream }) \\
10 \mathrm{Gbit} / \mathrm{s} / \mathrm{ch} \\
(\text { upstream }) \text { atau } \\
10 \mathrm{Gbit} / \mathrm{s} / \mathrm{ch} \\
(\text { downstream }) \\
2.5 \mathrm{Gbit} / \mathrm{s} / \mathrm{ch} \\
(\text { upstream }) \text { atau } \\
2.5 \mathrm{Gbit} / \mathrm{s} / \\
\mathrm{ch}(\text { downstream }) \\
2.5 \mathrm{Gbit} / \mathrm{s} / \mathrm{ch} \\
(\text { upstream })\end{array}$ & $\begin{array}{l}1 \mathrm{G}, 2.5 \mathrm{G} \text { dan } \\
10 \mathrm{G}\end{array}$ \\
\hline
\end{tabular}




\begin{tabular}{|c|c|c|c|c|}
\hline \multirow[b]{2}{*}{ Parameter } & \multirow[b]{2}{*}{ GPON $[10][13]$} & \multirow[b]{2}{*}{ XGPON[14] } & \multicolumn{2}{|c|}{ NG-PON2 } \\
\hline & & & $\begin{array}{c}\text { TWDM PON[11] } \\
{[8]}\end{array}$ & $\begin{array}{l}\text { PtP WDM } \\
\text { PON[12][8] }\end{array}$ \\
\hline $\begin{array}{l}\text { Pita Panjang } \\
\text { Gelombang }\end{array}$ & $\begin{array}{l}\text { Downstream: } 1490 \\
\mathrm{~nm} \text { dan } 1550 \mathrm{~nm} . \\
\text { Upstream: } 1310 \\
\mathrm{~nm}\end{array}$ & $\begin{array}{l}\text { Downstream: } \\
1575-1580 \mathrm{~nm} \\
\text { Upstream: } \\
1260-1280 \mathrm{~nm}\end{array}$ & $\begin{array}{l}\text { Downstream: } 1596- \\
1603 \mathrm{~nm} \\
\text { Upstream: } \\
1524-1544 \mathrm{~nm} \text { (wide } \\
\text { band) } \\
\begin{array}{l}1528-1540 \\
\text { (reduced band) }\end{array} \\
\begin{array}{l}1532-1540 \\
(\text { narrow band) }\end{array} \\
\end{array}$ & $\begin{array}{l}1524-1625 \mathrm{~nm} \\
\text { (expended } \\
\text { spectrum) } \\
1603-1625 \mathrm{~nm} \\
\text { (shared } \\
\text { spectrum) }\end{array}$ \\
\hline
\end{tabular}

JURNAL

MANAJEMEN

INDONESIA

Jaringan GPON dan XGPON dapat dimigrasikan ke NG-PON2 melalui 2 cara yaitu skenario migrasi brownfield dan skenario migrasi straight (ITU-T G.989.1, 2008). Skenario migrasi browfield adalah jenis skenario migrasi dimana operator tidak perlu mengganti atau mengganggu jaringan dan layanan eksisting bilamana operator ingin meng-upgrade jaringannya dengan teknologi baru sehingga jaringan eksisting dapat berdampingan dengan jaringan baru. Sebagai contoh operator dapat membangun jaringan NG-PON2 tetapi tidak mengganggu jaringan dan layanan GPON atau XGPON. Sedangkan skenario migrasi straight adalah jenis skenario migrasi dimana operator harus mengganti atau mengganggu jaringan dan layanan eksisting bilamana operator ingin mengupgrade jaringannya dengan teknologi baru. Sebagai contoh operator dapat membangun jaringan NG-PON2 tetapi harus mengganti semua perangkat GPON atau XGPON diganti dengan perangkat NG-PON2. Pemilihan skenaro migrasi ini sangat tergantung tingkat kepentingan dan bisnis.

Ada beberapa keuntungan yang dapat diambil oleh operator dengan implementasi NG-PON2 antara lain sebagai berikut :

a. Memiliki kapasitas jaringan yang besar sehingga dapat mengintegerasikan berbagai jenis teknologi dan layanan termasuk teknologi untuk menyediakan jaringan akses radio.

b. Memiliki jangkauan layanan yang luas dapat mencapai $40 \mathrm{~km}$ (ITU-T G.989.2, 2015)

c. Dapat menyalurkan layanan triple play (suara, data dan video) dengan kualitas layanan yang sangat baik ke pelanggan karena memiliki bandwidth yang lebar.

d. Dengan adanya kemampuan megintegerasikan berbagai jenis layanan dan teknologi maka dapat menekan biaya CAPEX dan OPEX, mempercepat penggelaran layanan ke pelanggan serta memudahkan operasi dan pemeliharaan.

e. Dapat dibangun tanpa mengganggu layanan eksisting.

Dengan melihat keuntungan-keuntungan yang bisa diambil, maka diyakini bahwa NG-PON2 dapat dijadikan solusi jangka panjang untuk menyediakan layanan ke pelanggan dengan kualitas layanan yang baik.

\section{Metodologi Penelitian}

\subsection{Kerangka Kerja}

Kerangka kerja penelitian ini dapat dilihat pada gambar 6. Pada penelitian ini melakukan pengumpulan data eksternal dan pengumpulan data internal. Selanjutnya data-data tersebut dianalisa dan diformulasikan sebagai sebagai dasar pembuatan strategi implementasi. 


\section{JURNAL}

MANAJEMEN

INDONESIA

Vol. 17 - No. 1

April 2017

\section{Gambar 6.}

Kerangka Kerja

Penelitian

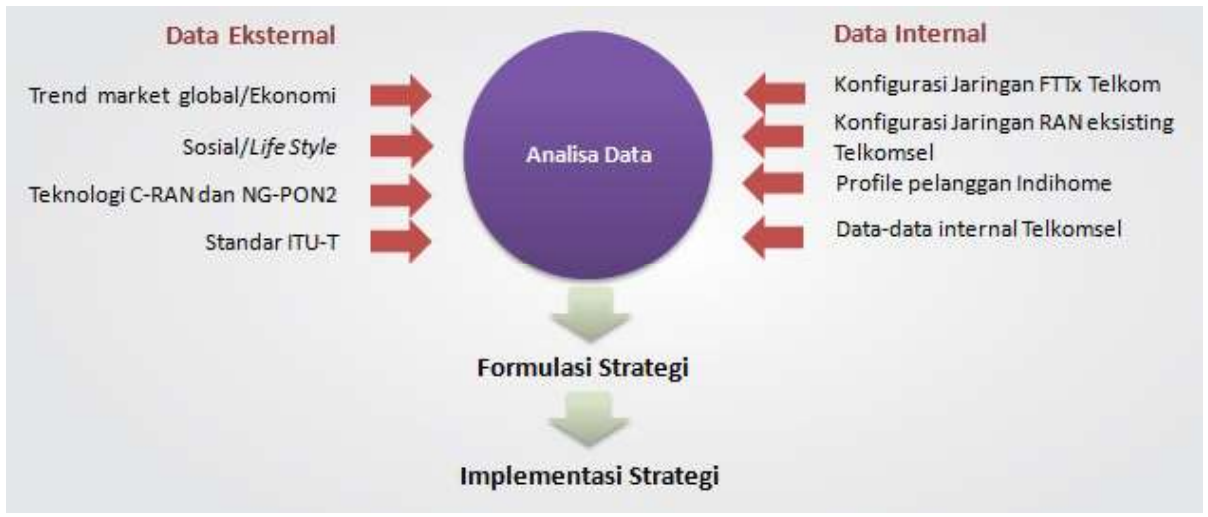

\subsection{Metode Pengumpulan Data}

Metode pengumpulan data yang digunakan di sini antara lain sebagai berikut :

1) Studi pustaka

Pengumpulan data antara lain bertujuan untuk membuat landasan teori dan sebagai data masukan dalam membuat analisa. Dokumen-dokumen dari hasil studi pustaka berupa jurnal, standar internasional serta dokumen-dokumen penelitian.

2) Brainstorming

Pengumpulan data melalui melakukan brainstorming dengan para ahli bertujuan untuk sebagai bahan analisa dan merumuskan strategi implementasi.

\subsection{Metode Analisis}

Pada tulisan ini menggunakan metode analisis kualitatif dengan menggunakan pendekatan strategy situation analysis (SSA) yaitu melakukan analisa data eksternal maupun internal dan selanjutnya diformulasikan sebagai dasar pembuatan strategi implementasi.

\section{Pembahasan}

\subsection{Data dan Analisa Sosial Ekonomi}

Berdasarkan dokumen The Mobile Economy 2016, GSM Association, 2016 (GSM Association, 2016), diperkirakan jumlah pelanggan mobile total secara global mengalami pertumbuhan dari tahun 2015 sebesar 4,7 milyar menjadi sebesar 5,6 milyar pada tahun 2020 atau dengan CAGR sebesar 3,9\%. Kenaikan jumlah pelanggan ini juga diikuti dengan kenaikan jumlah smart phone dari tahun 2015 sebesar 2,6 milyar menjadi 5,8 Milyar tahun 2020 dan pertumbuhan trafik data dengan CAGR sebesar 49\% (tahun 2015 - 2020). Berdasarkan data dokumen Telkomsel (Master Plan Network Telkomsel, 20152019), pertumbuhan pelanggan Telkomsel akan cenderung melambat sejak tahun 2014 - 2019 dengan CAGR 3\% lihat gambar 7. Adopsi teknologi oleh pelanggan melalui penggunaan smart phone menunjukkan adanya pertumbuhan pelanggan $3 \mathrm{G}$ sebesar CAGR 15\% dan diprediksi semakin banyak pelanggan yang menggunakan smart phone berbasis teknologi 4G dengan pertumbuhan CAGR 91\%. 


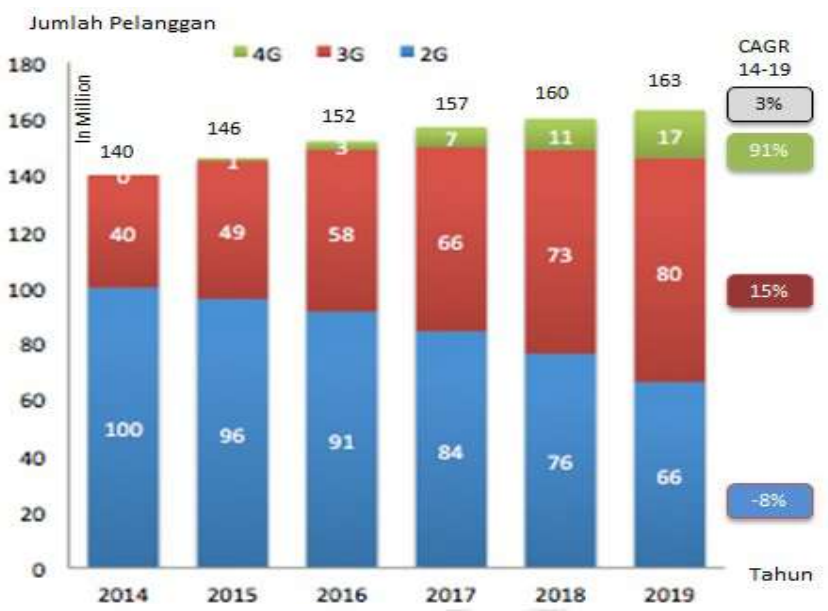

Pertumbuhan trafik data salah satunya disebabkan karena perubahan life style dari pelanggan. Berdasarkan dokumen Ericsson Mobility Report On The Pulse of The Networked Society, Nopember 2016 (Ericsson, 2016) Diperkirakan dari tahun 2016 sampai dengan tahun 2022, pertumbuhan pengguna aplikasi video lebih tinggi dibandingkan aplikasi yang lain bahkan diperkirakan pada tahun 2022 aplikasi video akan mendominasi mobile traffic yaitu kurang lebih $75 \%$ lihat gambar 8 .

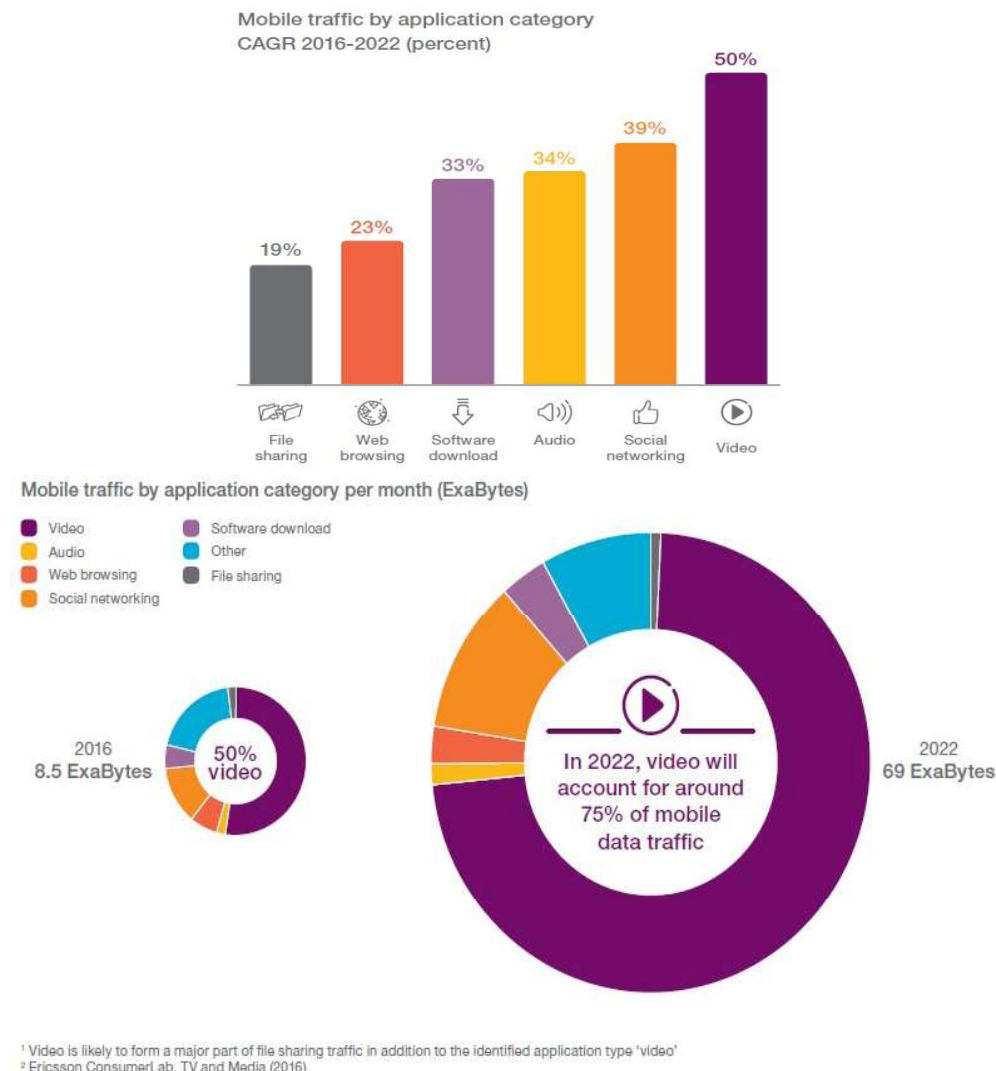

Menurut data dari We Are Social bulan januari 2017, pengguna internet saat ini mencapai 3,773 milyar dengan penetrasi $50 \%$, sementara itu orang yang aktif dalam menggunakan media sosial sebanyak 2,789 Milyar dengan penetrasi 37\% (lihat gambar 9).

Bagaimana dengan Indonesia? Dengan penetrasi 51 persen, kini pengguna internet di Indonesia mencapai 132,7 juta pengguna. 106 juta di antaranya merupakan pengguna media sosial aktif. Angka yang tidak mengherankan, mengingat Indonesia merupakan salah satu negara teraktif di media sosial. Sementara itu koneksi perangkat mobile sudah mencapai 371,4 juta dan pengguna media sosial aktif dengan perangkat mobile mencapai 92 juta (lihat gambar 9).
JURNAL

MANAJEMEN

INDONESIA

Vol. 17 - No. 1

April 2017

Gambar 7.

Kecenderungan dan

perkiraan pertumbuhan

pelanggan Telkomsel

(Sumber: Master Plan

Network Telkomsel,

2015-2019)

Gambar 8.

Trafik mobile

berdasarkan kategori

aplikasi (Sumber:

Ericsson, 2016) 


\section{JURNAL}

MANAJEMEN

INDONESIA

\section{Vol. 17 - No. 1}

April 2017

\section{Gambar 9.}

Data Statistik Pengguna Internet dan Media Digital Di Dunia dan Indonesia (Sumber: https://wearesocial. com/)

\section{Gambar 10.}

Pertumbuhan Trafik Data vs Revenue

\section{Gambar 11.}

Cost vs Revenue pada Jaringan Mobile

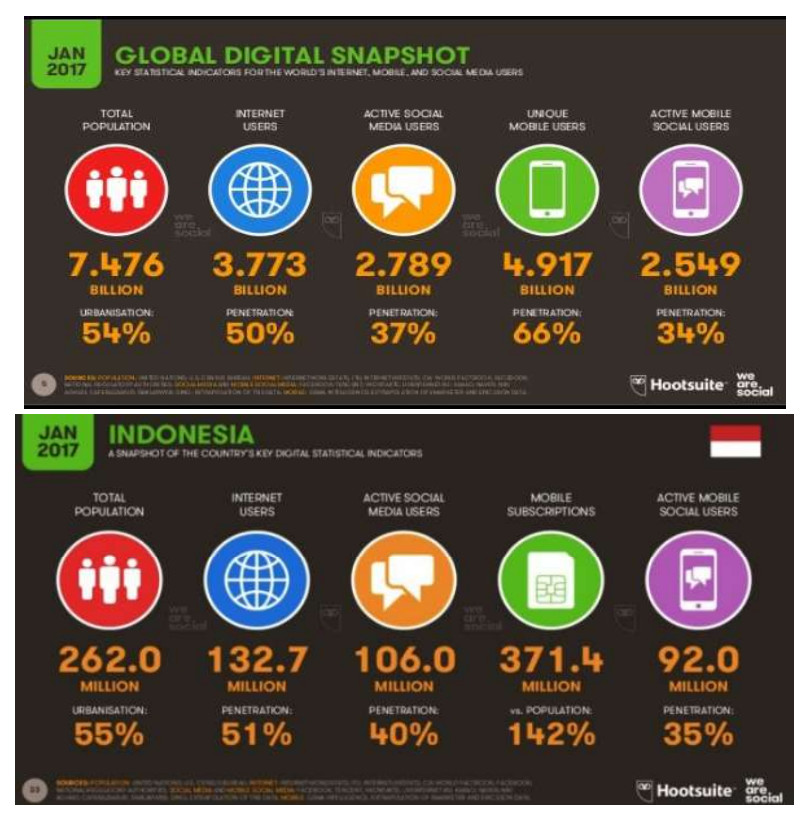

Namun demikian besarnya pertumbuhan trafik data mobile tidak sebanding dengan petumbuhan dari revenue yang didapat oleh mobile operator sehingga munculah gap. Gap muncul disebabkan oleh besarnya biaya CAPEX dan OPEX yang harus dikeluarkan perusahaan tidak sebanding dengan revenue yang didapatkan. Berdasarkan hasil survei dari Juniper Research tahun 2011 (lihat gambar 11), diperkirakan adanya kecenderungan beban biaya yang dikeluarkan oleh mobile operator semakin besar dibandingkan besar revenue yang didapatkan.
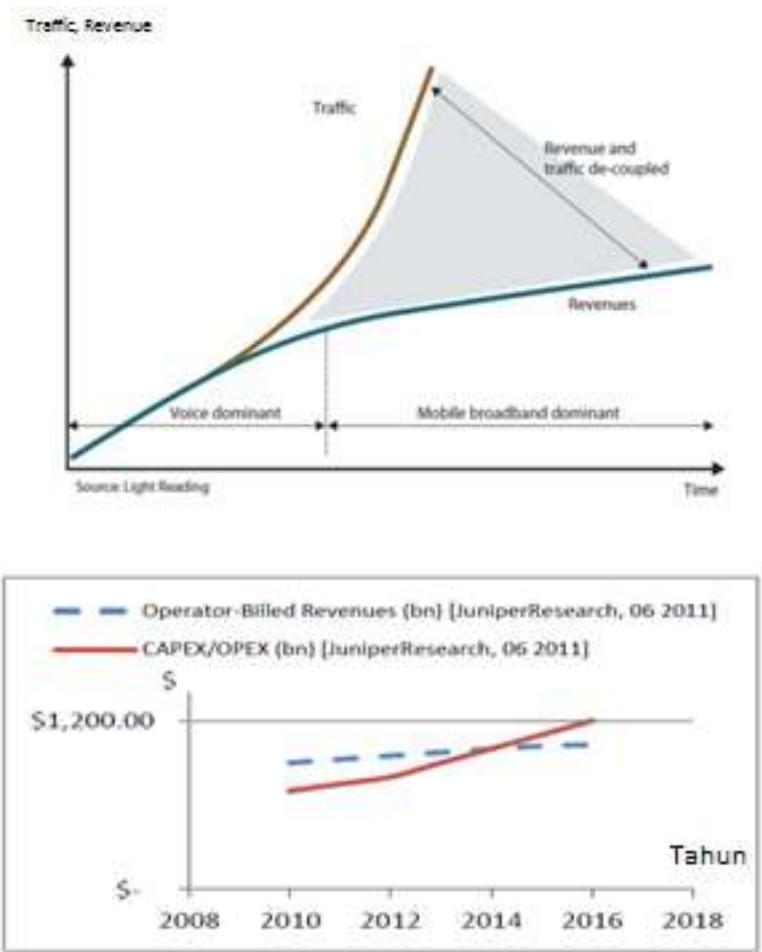

Demikian pula di Indonesia, rata-rata nilai OPEX dari mobile operator mengalami kenaikan untuk setiap tahunnya. Kenaikan nilai expenses tidak serta merta berbanding lurus terhadap kenaikan revenue (Zaid, 2015) Lihat gambar 12,13 dan gambar 14. 


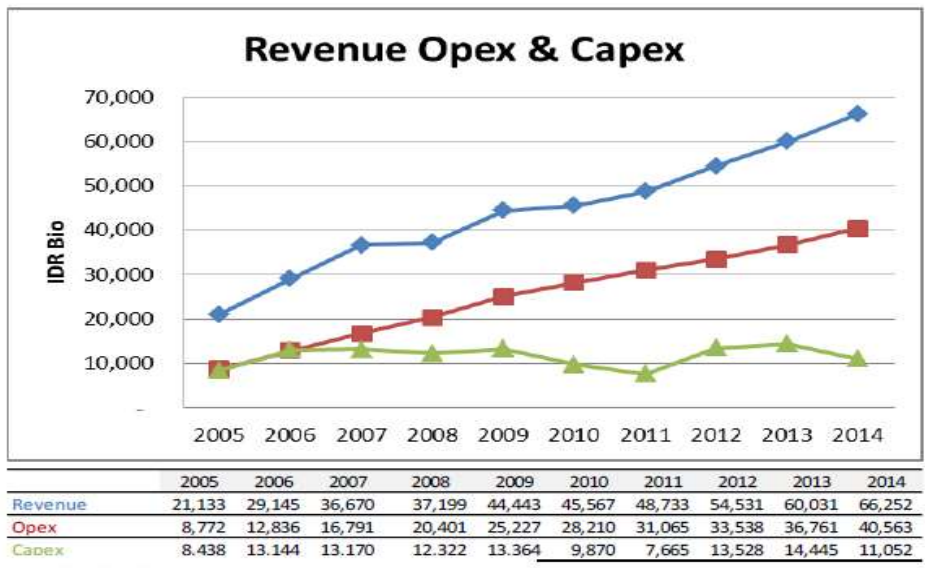

\section{JURNAL \\ MANAJEMEN \\ INDONESIA}

Vol. 17 - No. 1

April 2017

Gambar 12.

Revenue vs CAPEX/

OPEX Telkomsel (Zaid,

2015)
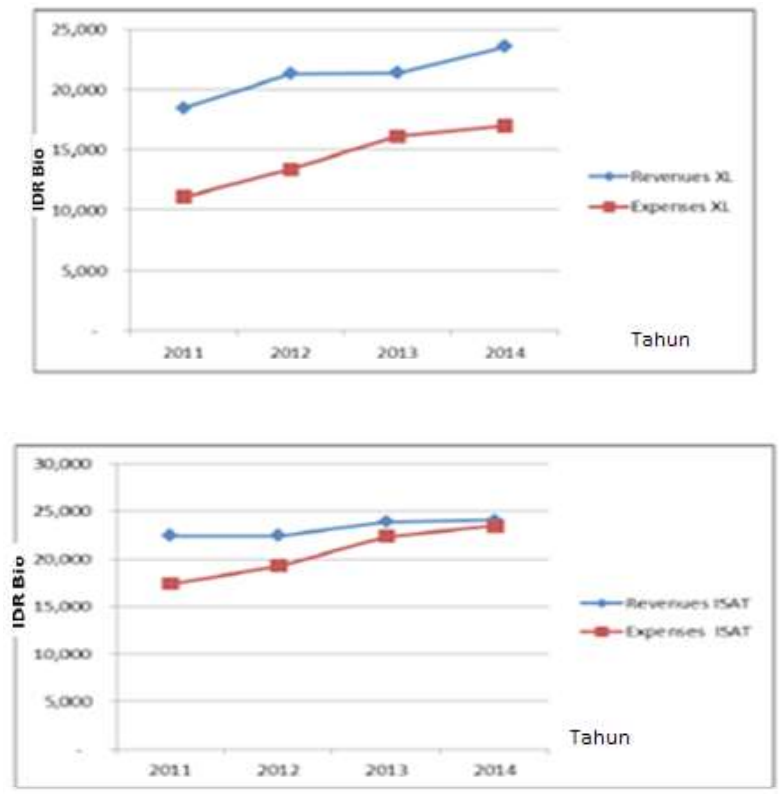

Gambar 13.

Revenue vs Expenses

XL (Zaid, 2015)

Gambar 14. Revenue vs

Expenses Indosat (Zaid,

Dengan adanya trend kenaikan jumlah pelanggan mobile dan juga pengguna internet maka dapat dijadikan peluang bagi operator telekomunikasi untuk mendapatkan tambahan revenue melalui penambahan jumlah pelanggan mobile dan penambahan penggunaan layanan data. Sedangkan tantangan ke depan adalah bagaimana menyediakan resources termasuk penambahan kapasitas jaringan yang efisien sehingga pertumbuhan revenue jauh lebih tinggi dari pertumbuhan biaya yang harus dikeluarkan oleh operator.

\subsection{Data dan Analisa Teknologi}

Dalam rangka menekan biaya OPEX dan CAPEX yang harus dikeluarkan oleh mobile operator dalam meningkatkan jaringan akses maka muncullah konsep arsitektur Cloud Radio Access Network (C-RAN). Berdasarkan hasil penelitian (C-RAN, 2013), dibandingkan dengan Radio Access Network (RAN) tradisional, C-RAN mampu menekan biaya CAPEX sebesar 30\% dan OPEX sebesar 53\% (C-RAN, 2013). Berdasarkan kajian dari Maravedis-Rethink (Gabriel, 2013), pada tahun 2018 sekitar $40 \%$ dari mobile operator di dunia akan menggunakan C-RAN pada area-area tertentu, tetapi tiga per empatnya akan menggunakan arsitektur hybrid dimana mengkombinasikan antara arsitektur C-RAN dengan arsitektur RAN tradisional. Maravedis-Rethink juga memprediksikan C-RAN akan menjadi pilihan mobile operator karena mampu menekan TCO (Total Cost of Ownership) serta memiliki fleksibilitas yang tinggi dalam menyediakan layanan ke pelanggan. Sampai tahun 2020, diperkirakan kurang lebih 300.000 BTS makro akan dilengkapi dengan fasilitas C-RAN dimana akan mendukung kurang lebih 1 juta sub-site yang dihubungkan melalui kabel serat optik maupun radio, lihat gambar 15. Sedangkan berdasarkan survei OVUM pada tahun 2Q15 (Dimitris, 2015) lihat gambar 16, dalam 2-3 tahun ke depan sebanyak 34\% mobil operator dalam 
meningkatkan kemampuan jaringan akses radionya dengan cara mengimplementasikan C-RAN/Cloud RAN.

\section{JURNAL}

MANAJEMEN

INDONESIA

Vol. 17 - No. 1

April 2017

\section{Gambar 15.}

Prediksi jumlah BTS makro yang akan menggunakan CRAN (Gabriel, 2013)

\section{Gambar 16.}

Hasil survei mobil operator dalam menggunakan meningkatkan kemampuan jaringan akses radio (Dimitris, 2015)

\section{Gambar 17.}

Hasil survei mobile operator terhadap tantangan implementasi C-RAN (Sumber:

Dimitris, 2015)
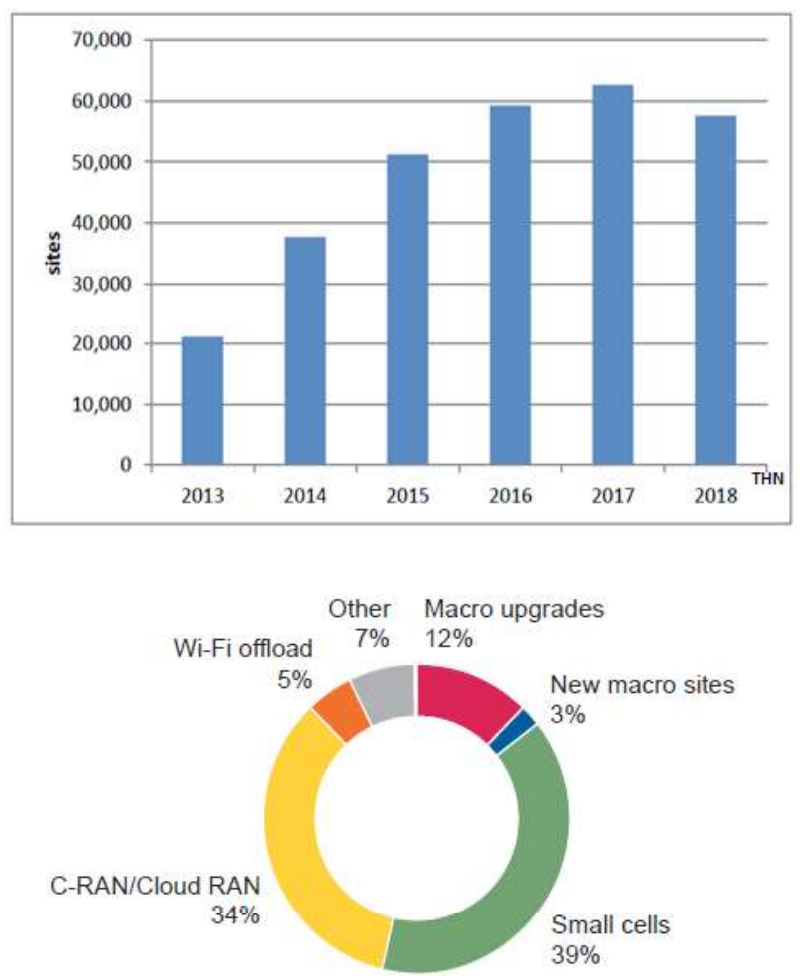

Dalam mendesain jaringan C-RAN tidak terlepas dari desain jaringan fronthaul karena berdasarkan survei dari OVUM tahun 2015 [19] (lihat gambar 17) menyatakan bahwa tantangan terbesar dari implementasi C-RAN adalah penyediaan jaringan fronthaul khususnya penyediaan jaringan fiber optik. Oleh karena itu sangat perlu operator memilih jaringan fronthaul yang tepat.

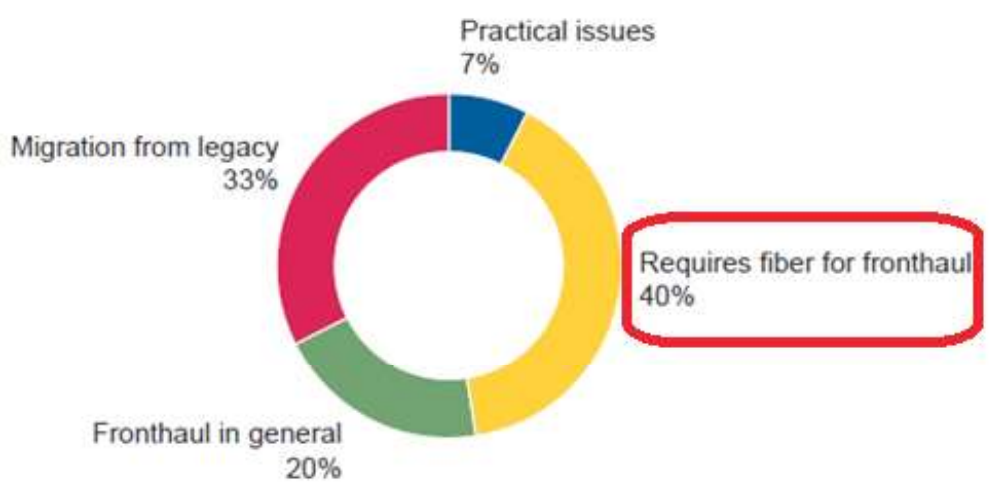

Saat ini, ada beberapa teknologi yang dapat digunakan untuk menyediakan jaringan fronthaul C-RAN antara lain dark fiber (dedicated fiber), Coarse Wavelength Division Multiplexing (CWDM), DWDM/OTN, NG-PON2 serta melalui E-Band Microwave. Setiap teknologi memiliki keunggulan dan kelemahan masing-masing sehingga dalam implementasinya harus mempertimbangkan banyak hal sesuai dengan kebutuhan antara lain mencakup kapasitas yang dibutuhkan, kondisi infrastruktur yang telah tersedia, kondisi geografis, tingkat kehandalan serta faktor biaya. Analisa keperuntukkan untuk macam-macam jaringan fronthaul tersebut dapat dilihat pada tabel 2. Sedangkan ringkasan karakteristik dari masing-masing jaringan fronthaul dapat dilihat pada tabel 3. 


\begin{tabular}{|c|c|}
\hline Teknologi & Keperuntukan \\
\hline Dark Fiber & $\begin{array}{l}\text { Jaringan dark fiber digunakan bila dengan kondisi sebagai berikut: } \\
\text { - } \quad \text { Telah tersedia cukup banyak serat optik pada jaringan eksisting yang } \\
\text { terpasang pada setiap cell site. } \\
\text { - Kapasitas jaringan yang dibutuhkan tidak besar karena untuk } \\
\text { menaikkan kapasitas harus menarik kabel baru sehingga kurang } \\
\text { praktis. } \\
\text { Digunakan sebagai solusi short term atau solusi sementara/antara. }\end{array}$ \\
\hline$C W D M$ & $\begin{array}{l}\text { Jaringan dengan menggunakan CWDM digunakan bila dengan kondisi } \\
\text { sebagai berikut: } \\
\text { - Bilamana ingin meng-upgrade jaringan dark fiber dalam rangka } \\
\text { meningkatkan kapasitas. } \\
\text { - Digunakan sebagai solusi short term atau solusi sementara/antara } \\
\text { dengan memanfaatkan jaringan eksisting. } \\
\text { - Karena perangkat CWDM tidak membutuhkan daya maka sangat } \\
\text { cocok untuk solusi luar ruangan (outdoor). } \\
\text { - Untuk skala jaringan yang tidak besar. }\end{array}$ \\
\hline$N G-P O N 2$ & $\begin{array}{l}\text { Solusi dengan menggunakan teknologi NG-PON2 merupakan solusi yang } \\
\text { sangat potensial dengan mensinergikan jaringan fixed fiber Telkom untuk } \\
\text { Indihome sehigga dapat membangun jaringan C-RAN dengan cepat dan } \\
\text { cakupan layanan yang luas. Jadi jaringan dengan menggunakan teknologi } \\
\text { NG-PON2 digunakan bila dengan kondisi sebagai berikut: } \\
\text { - Adanya kolaborasi jaringan akses fiber sehingga ada pemanfaatan } \\
\text { jaringan eksisting fiber untuk layanan fixed broadband FTTx maupun } \\
\text { C-RAN. } \\
\text { Cocok untuk jaringan small cell. }\end{array}$ \\
\hline$E-B$ and $M W$ & $\begin{array}{l}\text { Jaringan fronthaul dengan teknologi E-Band Microwave digunakan bila } \\
\text { dalam kondisi sebagai berikut: } \\
\text { - Daerah yang tidak lagi memungkinkan untuk penggelaran kabel } \\
\text { optik. } \\
\text { - Jaringan dengan skala tidak besar. } \\
\text { - Sebagai solusi sementara atau antara dalam rangka penggelaran } \\
\text { layanan ke pelanggan dengan cepat. } \\
\text { - Jarak jangkauan tidak jauh. }\end{array}$ \\
\hline$D W D M / O T N$ & $\begin{array}{l}\text { Solusi jaringan fronthaul untuk C-RAN dengan menggunakan } \\
\text { teknologi DWDM/OTN adalah solusi yang sangat mahal sehingga dapat } \\
\text { menghilangkan konsep lahirnya arsitektur C-RAN yang mampu menekan } \\
\text { biaya CAPEX dan OPEX. Jadi solusi ini digunakan bilamana jaringan } \\
\text { Telkomsel benar-benar dalam kondisi extraordinary dimana untuk } \\
\text { meningkatkan kemampuan jaringan fronthaul sudah tidak ada alternatif } \\
\text { lain sementara kebutuhan layanan ke pelanggan sudah mendesak. }\end{array}$ \\
\hline
\end{tabular}

\begin{tabular}{|l|c|c|c|c|c|}
\hline \multicolumn{1}{|c|}{ Parameter } & Dark Fiber & CWDM & NG-PON2 & $\begin{array}{c}\text { E-Band } \\
\text { MW }\end{array}$ & $\begin{array}{c}\text { DWDM } \\
\text { /OTN }\end{array}$ \\
\hline Less Fiber & Tidak & Ya & Ya & Ya & Ya \\
OA\&M & Ya & Tidak & Ya & Ya & Ya \\
Trouble Shooting & Tidak & Tidak & Ya & Ya & Ya \\
Sistem proteksi & Tidak & Tidak & Tidak & Ya & Ya \\
\hline
\end{tabular}

Tabel 3.

Ringkasan Analisa Teknologi Jaringan Fronthaul 
JURNAL

MANAJEMEN

INDONESIA

Vol. 17 - No. 1

April 2017

\begin{tabular}{|l|c|c|c|c|c|}
\hline \multicolumn{1}{|c|}{ Parameter } & Dark Fiber & CWDM & NG-PON2 & $\begin{array}{c}\text { E-Band } \\
\text { MW }\end{array}$ & $\begin{array}{c}\text { DWDM } \\
\text { /OTN }\end{array}$ \\
\hline Biaya & Rendah & Sedang & Sedang & Sedang & Tinggi \\
Skalabilitas & Rendah & Rendah & Tinggi & Rendah & Tinggi \\
Kapasitas & Rendah & Sedang & Sedang & Rendah & Tinggi \\
Foot print & Tidak & Tidak & Ya & Tidak & Ya \\
\hline
\end{tabular}

Dari tabel 2 dan tabel 3 menunjukkan bahwa NG-PON2 merupakan salah satu kandidat yang banyak dipilih operator termasuk PT, TELKOM untuk diimplementasikan jaringan fronthaul C-RAN karena dapat mengefektifkan jaringan serat optik eksisting yang telah tersedia untuk layanan fixed broadband. Di samping itu dengan adanya kolaborasi C-RAN dengan jaringan FTTx melalui teknologi NG-PON2 maka akan menyediakan layanan wireless broadband ke pelanggan dengan lebih cepat dan jangkauan layanan yang luas.

\section{Formulasi dan Implementasi Strategi}

Berdasarkan analisa sosial, ekonomi dan teknologi pada bab 4 maka dapat dibuat formulasi strategi implementasi C-RAN di Telkomsel melalui kolaborasi jaringan NGPON2 di Telkom Akses yaitu sebagai berikut :

1) Strategi bagaimana melakukan migrasi jaringan PON FTTx Telkom Akses eksisting ke jaringan NG-PON2.

2) Strategi bagaimana melakukan migrasi jaringan RAN eksisting Telkomsel ke jaringan C-RAN

3) Strategi bagamana melakukan kolaborasi jaringan C-RAN Telkomsel dengan jaringan NG-PON2 Telkom Akses.

\subsection{Strategi Migrasi Jaringan PON FTTx Telkom Akses ke NG-PON2}

Kunci sukses dalam memigrasikan jaringan PON FTTx Telkom Akses eksisting ke jaringan NG-PON2 adalah antara lain dipastikan tidak adanya perubahan atau persyaratan tambahan yang diperlukan dalam jaringan akses serat optik sehingga NG-PON2 harus mampu menggunakan jaringan akses serat optik eksisting. Berdasarkan kondisi eksisting jaringan PON FTTx Telkom Akses maka ada 2 skenario migrasi jaringan GPON/ XGPON FTTx ke NG-PON2 yaitu skenario migrasi brownfield dan skenario migrasi straight. Pada skenario migrasi brownfield Telkom Akses perlu menambahkan perangkat yang bernama coexistence element (CEx) pada sentral. Dengan perangkat CEx maka Telkom Akses dapat membangun jaringan NG-PON2 tanpa mengganggu jaringan PON legacy yaitu GPON atau XGPON FTTx Telkom untuk layanan Indihome. Sehingga antara jaringan NG-PON2, GPON dan XGPON dapat berdampingan (co-existence). Kunci dari skenario migrasi brownfield ini adalah adanya perangkat CEx berupa filter WDM (Wavelength Division Multiplexing) yang berfungsi melakukan filter panjang gelombang yang digunakan untuk GPON, XGPON dan NG-PON2. Sementara itu dengan menggunakan skenario migrasi straight, NG-PON2 mengganti semua perangkat dari PON eksisting, hanya memanfaatkan jaringan akses fiber serta passive splitter. Jadi pada skenario migrasi ini tidak dibutuhkan adanya perangkat co-existence element. Untuk memperjelas perbedaan skenario migrasi brownfield dan straight dapat dilihat pada gambar 18 dan gambar 19.

Gambar 18.

Arsitektur NG-PON2

melalui skenario

migrasi brownfield

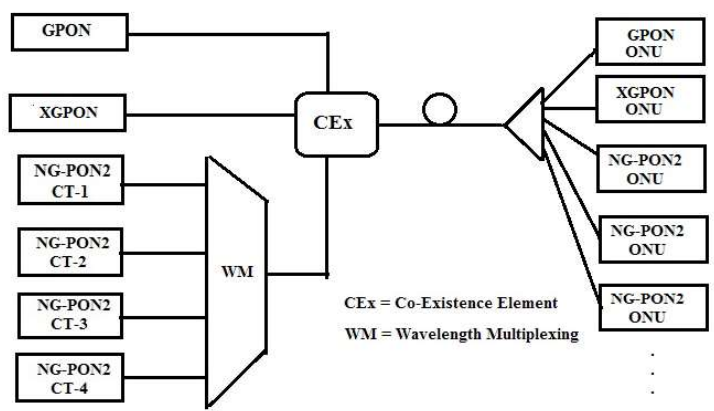

Jurnal Manajemen Indonesia 


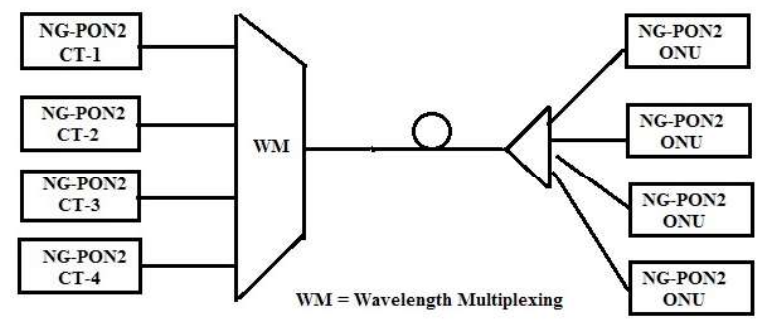

PT. Telkom Akses (PTTA) sebagai anak perusahan PT. Telkom yang bertanggung jawab mengelola infrastruktur jaringan akses serat optik, dalam memilih skenario migrasi yang akan dipilih harus mempertimbangkan pengimplementasinya seperti yang dijelaskan pada tabel 4 .

\section{Skenario Migrasi Brownfield}

Skenario Migrasi Straight

Membutuhkan co-existence element (WDM filter) yang digunakan untuk mem-filter panjang gelombang yang digunakan untuk PON eksisting dengan NG-PON2.

ONU dan OLT dan jaringan distribusi kabel optik serta passive splitter eksisting masih digunakan.

Digunakan bilamana dalam satu area masih ada pelanggan eksisting yang tidak membutuhkan bandwidth besar, sehingga masih ada pendapatan walaupun dalam jumlah tidak besar per pelanggan.

Sebagai solusi antara sebelum melakukan migrasi ke tahap NG-PON2.

Membutuhkan CAPEX yang lebih besar (Ahsan, 2014)
Tidak membutuhkan co-existence element (WDM filter) karena tidak adanya layanan PON eksisting.

Semua ONU dan OLT eksisting diganti dengan dengan ONU dan OLT NG-PON2. Jaringan distribusi kabel optik dan passive splitter eksisting masih digunakan.

Digunakan bilamana dalam satu area semua atau sebagian besar pelanggan eksisting mulai membutuhkan bandwidth besar atau dalam suatu area perumahan baru yang belum ada jaringan PON.

Solusi akhir dari migrasi PON eksisting.

Membutuhkan CAPEX yang lebih kecil.

Dari penjelasan pada tabel di atas maka untuk menentukan skenario migrasi yang digunakan harus melihat profile dari pelanggan indihome saat ini berdasarkan prosentase paket yang digunakan seperti tampak pada tabel 5 .

\begin{tabular}{cc}
\hline Paket Internet & Prosentase \\
\hline $384 \mathrm{~K}$ & 3,04 \\
$512 \mathrm{~K}$ & 7,06 \\
$1 \mathrm{M}$ & 43,45 \\
$2 \mathrm{M}$ & 8,05 \\
$3 \mathrm{M}$ & 9,56 \\
$5 \mathrm{M}$ & 2,93 \\
$10 \mathrm{M}$ & 24,28 \\
$20 \mathrm{M}$ & 1,18 \\
$50 \mathrm{M}$ & 0,17 \\
$100 \mathrm{M}$ & 0,04 \\
\hline
\end{tabular}

Tabel 5.

Profile Jumlah

Pelanggan Indihome Berdasarkan Paket Internet

( Jumlah Pelanggan= 1,66 Juta) (Sumber : CSLI Indihome 2015) 


\section{JURNAL}

MANAJEMEN

INDONESIA

Vol. 17 - No. 1

April 2017

Gambar 20.

Migrasi Jaringan

Eksising Telkomsel ke Arsitektur C-RAN
Berdasarkan analisa skenario migrasi pada tabel 4 dan profil pelanggan Indihome pada tabel 5 maka skenario migrasi GPON/XGPON ke NG-GPON2 yang dipilih PT. Telkom Akses untuk saat ini adalah menggunakan skenario migrasi brownfield karena masih sangat banyaknya pelanggan yang belum membutuhkan bandwidth besar. Penggelaran jaringan full NG-PON2 dilakukan untuk jangka panjang dimana diperuntukkan pada area-area perumahan-perumahan baru dan besar, pusat perbisnisan dan area metropolitan yang kebutuhan bandwidthnya besar.

\subsection{Strategi Migrasi RAN Eksisting Telkomsel ke C-RAN}

Radio Access Network (RAN) tradisional eksisting Telkomsel dapat dimigrasikan secara halus ke arah Cloud RAN melalui 3 fase yaitu fase sentralisasi BBU, BBU pooling dan virtual RAN (NGMN, 2013). Pada tahap pertama adalah memindahkan setiap BBU di setiap site ke dalam satu lokasi dan menghubungkan perangkat remote radio unit (RRU) ke arah BBU dengan menggunakan jaringan fronthaul. Pada tahap ke dua adalah melakukan proses BBU pooling. Pada tahap ini dilakukan proses load balancing antara BBU dan proses redudansi untuk memproteksi sistem bilamana terjadi gangguan pada BBU. Manfaat yang diambil dengan sistem BBU pooling ini adalah mengurangi CAPEX karena jumlah BBU yang dibutuhkan berkurang, meningkatkan skalabilitas dan meningkatkan kehandalan. Tahap terakhir melakukan virtulasisi RAN yaitu setiap fungsi-fungsi pada BBU dilakukan proses virtualisasi.

Jaringan RAN LTE Telkomsel bila dimigrasikan ke arah C-RAN dapat diilustrasikan seperti gambar 20. Dengan arsitektur C-RAN, setiap BBU (eNodeB) yang terletak pada cell site dipindahkan ke satu tempat (centralized).

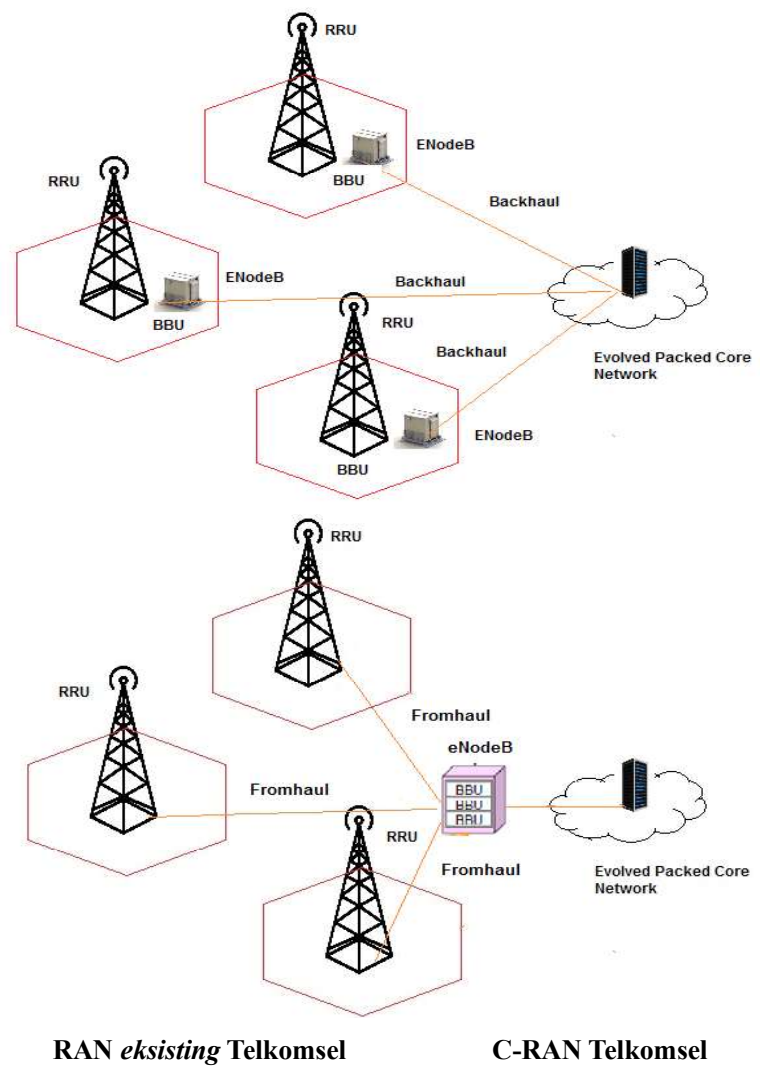

\subsection{Strategi Kolaborasi C-RAN Telkomsel dengan FTTx PT. Telkom Akses}

Adanya kemampuan NG-PON2 dalam mengintegrasikan beberapa jenis layanan baik layanan fixed broadband maupun mobile broadband dalam satu jaringan akses maka dapat menjadi peluang bagi PT. Telkom untuk mensinergikan anak perusahaanperusahaannya yaitu PT. Telkomsel dan PT. Telkom Akses untuk mengkolaborasikan penggunaan jaringan akses optiknya. Adapun manfaat dari kolaborasi jaringan tersebut bagi PT. Telkom antara lain : 
a. Menghemat biaya CAPEX

Komponen biaya CAPEX yang dapat dihemat antara lain biaya pengadaan dan penggelaran kabel optik bagi Telkomsel. Melalui arsitektur C-RAN dimana setiap BBU (Base Band Unit) di-pool dalam suatu tempat misalnya dalam satu gedung sentral Telkom maka dapat menekan biaya pengadaan untuk air conditioning (ac), shelter, pekerjaaan sipil, perangkat catu daya seperti genset batere dan rectifier.

b. Menghemat biaya OPEX

Komponen biaya OPEX yang dapat dihemat antara lain biaya operasi dan pemeliharaan jaringan kabel optik. Melalui arsitektur C-RAN, Telkomsel dapat menekan biaya konsumsi listrik, operasi dan pemeliharaan BTS dan sewa site.

c. Mempercepat penggelaran layanan

Dengan sinergi penggunaan jaringan akses fiber optik Telkom Akses oleh Telkomsel maka akan lebih cepat bagi Telkomsel untuk menggelar layanan bila dibandingkan dengan harus menggelar jaringan optik sendiri.

d. Meningkatkan Quality of Experience bagi kustomer PT. Telkomsel

Dengan memanfaatkan jaringan akses FTTx Telkom yang sudah menyebar dimana-mana maka Telkomsel dapat membangun lebih banyak small cell sehingga dapat meningkatkan kualitas layanan ke pelanggan. Melalui arsitektur C-RAN dengan menggunakan jaringan NG-PON2 sebagai fronthaul maka kecepatan data yang dirasakan oleh pelanggan akan semakin kencang sehingga akan berdampak meningkatnya Quality of Experience (QoE).

e. Memudahkan operasi dan pemeliharaan jaringan akses serat optik

Dengan adanya kolaborasi jaringan akses serat optik maka Telkomsel maupun Telkom Akses tidak melakukan operasi dan pemeliharaan jaringan akses serat optik sendirisendiri.

Kunci sukses dalam mengkolaborasikan jaringan C-RAN Telkomsel dengan Jaringan NG-PON2 Telkom Akses adalah sinergi yang baik antara dua anak perusahaan PT. Telkom tersebut. Jadi sinergi adalah syarat mutlak agar kolaborasi dua jenis jaringan tersebut dapat dilaksanakan. Tahapan-tahapan dalam mengkolaborasikan jaringan C-RAN Telkomsel dan jaringan NG-PON2 FTTx Telkom Akses adalah sebagai berikut :

a. Telkomsel maupun Telkom Akses harus membuat peta jaringan untuk lokasi-lokasi yang akan diimplementasikan baik C-RAN maupun NG-PON2 berdasarkan tingkat kebutuhan saat ini maupun dalam rangka antisipasi kebutuhan demand untuk masa yang akan datang.

b. Telkomsel maupun Telkom Akses menentukan kebutuhan kapasitas bandwidth berdasarkan profile pelanggan dan trend kebutuhan bandwidth. Hal ini digunakan untuk menentukan berapa besar share bandwidth antara C-RAN dengan pelanggan FTTx.

c. Berdasarkan kapasitas bandwidth yang dibutuhkan dan yang tersedia maka Telkomsel dapat menentukan jenis site C-RAN yang akan diimplementasikan apakah dalam bentuk macro cell atau dalam bentuk beberapa small cell.

d. Berdasarkan lokasi site C-RAN yang akan dibangun dan kapasitas jaringan fronthaul yang dibutuhkan maka sangat menentukan apakah ONU untuk perangkat radio akan dihubungkan melalui ODP atau langsung dari ODC.

e. Melakukan desain jaringan C-RAN dan NG-PON2 seperti contoh pada gambar 21. 
JURNAL

MANAJEMEN

INDONESIA

Vol. 17 - No. 1

April 2017

Gambar 21.

Desain Jaringan C-RAN

Telkomsel Melalui

Kolaborasi Dengan

Jaringan NG-PON2

Telkom Akses

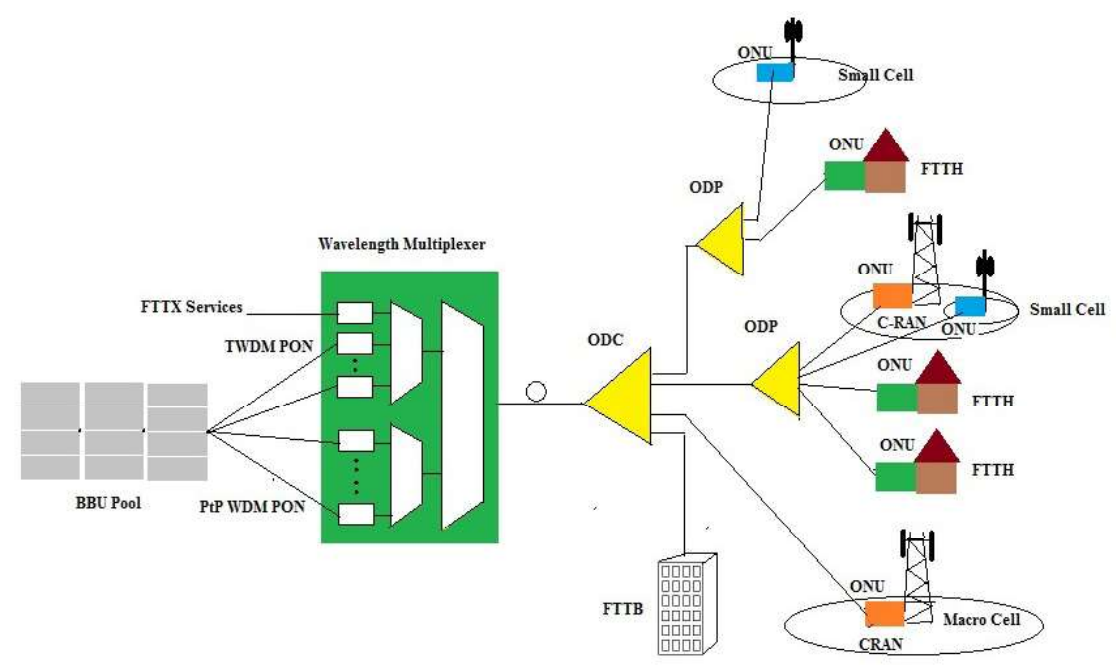

Berdasarkan hasil penjelasan tahapan kolaborasi di atas maka Telkom Akses dalam merencanakan pembangunan infrastruktur jaringan akses serat optik harus memperhatikan rencana pembangunan infrastruktur jaringan akses radio dari Telkomsel.

\section{Kesimpulan}

Implementasi C-RAN dengan memanfaatkan jaringan NG-PON2 sebagai jaringan fronthaul dapat memberikan solusi dalam meningkatkan kapasitas jaringan Telkomsel, perluasan jangkauan layanan, penggelaran layanan yang cepat, dapat menekan biaya CAPEX dan OPEX serta mempermudah operasi dan pemeliharaan jaringan akses serat optik. Melalui implementasi arsitektur C-RAN maupun NG-PON2 diyakini akan meningkatkan Quality of Experience kepada pelanggan disebabkan karena kapasitas jaringan semakin besar sehingga memungkinkan pelanggan dapat melakukan akses data dan internet semakin cepat serta dapat mengakses berbagai macam content dan layanan.

Ada beberapa strategi agar kolaborasi jaringan akses radio Telkomsel dengan jaringan akses eksisting Telkom Akses dapat berjalan dengan baik dan optimal yaitu strategi migrasi jaringan FTTx eksisting Telkom Akses ke jaringan NG-PON2, strategi migrasi jaringan RAN eksisting Telkomsel ke arsitektur C-RAN dan selanjutnya strategi bagaimana melakukan kolaborasi jaringan C-RAN Telkomsel dengan jaringan NGPON2 Telkom Akses. Kunci sukses kolaborasi jaringan ini adalah adanya komitmen dari managemen Telkomsel dan managemen Telkom Akses untuk melakukan sinergi dengan baik.

\section{Daftar Pustaka}

Ahsan, NS., Salleh, S., and Abdullah, F. 2014. Migration Strategy From Legacy PON System Into Next Generation PON System For Low CAPEX Telco Deployment in Malaysia.

Aleksandra, C., Henrik, LC., Yan, Y., Lara, S., Georgious, K., Michael, SB., and Larss, D. 2014. Cloud RAN for Mobile Networks-a Technology Overview, IEEE.

C-RAN. 2013. THE Road Towards Green RAN, White Paper, Version 3.0, China Mobile Research Institute.

Dimitris, M. 2015. Why Fronthaul Matters, A key Foundation for Centralized and Cloud RAN.

Ericsson. 2016. Ericsson Mobility Report on The Pulse of The Networked Society.

Gabriel, C. 2013. Tearing The Network Apart The Economics of The New RAN to 2018, Maravedis Rethink.

GSM Association. 2016. The Mobile Economy 2016.

https://wearesocial.com/ 
ITU-T G.984.1 Recommendation. 2008. Gigabit-capable passive optical networks (GPON): General characteristics.

ITU-T G.984.3 Recommendation. 2014. Gigabit-capable passive optical networks (GPON): Transmission covergence layer specification.

ITU-T G.987.1 Recommendation. 2016. 10-Gigabit-capable passive optical networks (XGPON): General requirement.

ITU-T G.989 Recommendation. 2015. 40-Gigabit-capable passive optical networks 2 (NGPON2): Definitions, abbreviations and acronyms.

ITU-T G.989.1 Recommendation. 2008. 40-Gigabit-capable passive optical networks (GPON): General requirements.

ITU-T G.989.2 Recommendation. 2015. 40-Gigabit-capable passive optical networks 2 (NGPON2): Physical Media Dependent (PMD) Layer Specification.

Martin, C., Derek, N., and Peter, D. 2015. FSAN Highlights \& NG-PON2 Standards Update.

Master Plan Network Telkomsel tahun 2015-2019.

NGMN. 2013. Suggestions on Potential Solutions To C-RAN.

Telkom Corporate University. Konfigurasi Fiber To The Home, PT. Telekomunikasi Indonesia.

Zaid, M. 8 July 2015. TELKOMSEL Financial Performance, A Procurement Perspective, NPD Sharing Session RAN \& Transmission Procurement Telkomsel. 
JURNAL

MANAJEMEN

INDONESIA

Vol. 17 - No. 1

April 2017 